\title{
Effects of nicotine on gastric myoelectrical activity in ICR mice
}

\author{
Eileen Hui-Chuan Wang ${ }^{1 *}$, Nathalie Percie Du Sert ${ }^{2}$, John Anthony Rudd ${ }^{1}$ \\ From 2011 International Conference on Molecular Neurodegeneration \\ Shanghai, China. 22-24 September 2011
}

\section{Background}

Slow waves originate from the pacemaker network of the interstitial cells of Cajal (ICC) and determine the direction and velocity of propagation of peristaltic activity of the gastrointestinal (GI) tract. The enteric nervous system (ENS) and smooth muscle cells are known to interface with ICCs through excitatory and inhibitory neurotransmitters. Electrogastrography (EGG) can be used to record gastric myoelectrical activity (GMA) and reveals slow wave information, in terms of frequency and power. GMA has been studied in conscious rabbits, dogs, rats, and ferrets, but rarely in mice. Nicotine was used to activate ganglia in an attempt to modulate excitatory and inhibitory neurons linked to ICC functioning. The aim of the present study, therefore, was to define the characteristics of GMA in mice, and to establish criteria for analysis.

\section{Methods}

16 male ICR mice (3 month old, 28-38 g) were anaesthetized and surgically implanted with telemetry devices (PhysioTel ${ }^{\circledR}$ ETA-F20, DSI) with recording wires sutured from the serosal surface of the stomach. 7 days later, baseline GMA recordings were obtained $2 \mathrm{~h}$ before injecting animals with nicotine $(3 \mathrm{mg} / \mathrm{kg}$, i.p.; $\mathrm{n}=8)$, or vehicle (saline $2 \mathrm{ml} / \mathrm{kg}$, i.p.; $\mathrm{n}=8$ ). Recordings then continued for a further $6 \mathrm{~h}$. Raw data (sampled at $1000 \mathrm{~Hz}$ ) were analyzed using Spike2 (Cambridge Electronic Design, U.K.). A low pass FIR filter was applied $(2.5 \mathrm{~Hz}$; transition gap: 10) to eliminate cardiac/respiratory signals. The waveform was then interpolated to $10.24 \mathrm{~Hz}$ before applying the second low pass FIR filter $(0.5 \mathrm{~Hz}$; transition gap: 0.1). The resultant waveform was then processed further by Fast Fourier Transformation (FFT)

'School of Biomedical Sciences, The Chinese University of Hong Kong, Hong Kong, SAR

Full list of author information is available at the end of the article to yield components of frequency. Two-way repeated measures ANOVA was performed to compare between the 8 vehicle- and 8 drug-treatment mice. A value of $\mathrm{P}<0.05$ was considered statistically significant.

\section{Results}

The dominant frequency (DF) of the baseline recordings of the vehicle and nicotine treatment groups were $6.8 \pm$ 0.4 and $6.6 \pm 0.4$ counts per min $(\mathrm{cpm})$, respectively. For the baseline recording of the vehicle and nicotine treatment groups, $40.9-41.8 \%$ of the power was in the normogastric range (DF $\pm 2 \mathrm{cpm}$ ). 9.1-9.7 \% and 26.6$26.6 \%$ of the power was in the bradygastric (0 to DF-2 $\mathrm{cpm})$ and tachygastric ranges $(\mathrm{DF}+2$ to $15 \mathrm{cpm})$, respectively. Saline had no effect on slow waves during the experiment $(n=8 ; P>0.05)$. Nicotine reduced the DF almost immediately to $5.9 \pm 0.5 \mathrm{cpm}(\mathrm{n}=8 ; \mathrm{P}<0.001)$ and produced a no-significant increase in \% power of bradygastria $(P>0.05)$. The effects of nicotine lasted for $2 \mathrm{~h}$ before the DF shifted back to pre-nicotine levels $(6.8 \pm$ $0.4 \mathrm{cpm})$. The \% power in tachygastria $(\mathrm{DF}+2$ to $15 \mathrm{cpm})$ was not affected by nicotine $(\mathrm{P}>0.05)$.

\section{Conclusion}

Nicotine, which is known to stimulate ganglia, caused bradygastria, suggesting an action to release inhibitory mediators to affect ICC. The studies demonstrate that radiotelemetry can be used to record GMA in conscious, freely moving mice, providing a convenient method to study GI functioning in a variety of circumstances. The studies were supported by a Direct Grant for Research (2006.2.034).

\footnotetext{
Author details

${ }^{1}$ School of Biomedical Sciences, The Chinese University of Hong Kong, Hong Kong, SAR. ²Division of Basic Medical Sciences, St. George's University of London, London, UK.
} 
doi:10.1186/1750-1326-7-S1-S13

Cite this article as: Wang et al:: Effects of nicotine on gastric

myoelectrical activity in ICR mice. Molecular Neurodegeneration 20127

(Suppl 1):S13.

Submit your next manuscript to BioMed Central and take full advantage of:

- Convenient online submission

- Thorough peer review

- No space constraints or color figure charges

- Immediate publication on acceptance

- Inclusion in PubMed, CAS, Scopus and Google Scholar

- Research which is freely available for redistribution 